\title{
Afghanistan RAMP Rebuilding Agricultural Markets in Afghanistan
}

Contract No. 306-C-00-03-00502-01

\section{RAMP 2004 Strategy Paper}

by

James Riordan

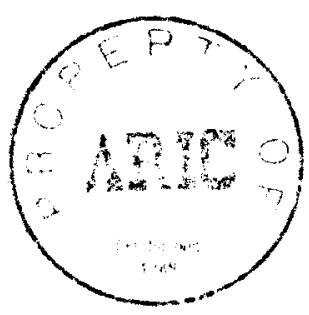

Submitted to:

U.S. Agency for International Development/Kabul

Submitted by:

Chemonics International Inc.

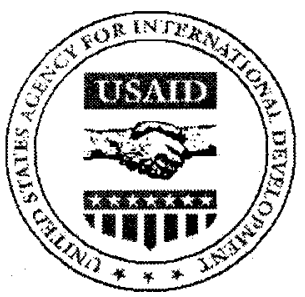

February 2004

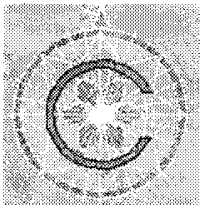

CHEMONICS

This publication was made possible through support provided by the U.S. Agency for International Development, under the terms of Award No. 306-C-00-03-00502-01. The opinions expressed herein are those of the author(s) and do not necessarily reflect the views of the U.S. Agency for International Development. 


\section{Rebuilding Afghanistan's Agricultural Markets Program (RAMP)}

On July 3, 2003, the U.S. Agency for International Development (USAID) issued a three-year contract to Chemonics International Inc. to implement the Rebuilding Afghanistan's Agricultural Markets (RAMP) program. The program aims to enhance food security and increase rural incomes in support of and in coordination with the Ministry of Agriculture and Animal Husbandry (MAAH). RAMP provides technical assistance, production finance, and infrastructure rehabilitation support to achieve those goals.

RAMP has two main operational objectives: increasing agricultural productivity and output; and increasing incomes through effective linkages among producers, processors, and markets.

\section{Increasing Agricultural Productivity and Output}

RAMP is launching a multi-pronged attack on key impediments to increasing productivity and output. In the first instance, the program is expanding the knowledge and use of improved technologies -new varieties, fertilizers, crop management and protection practices, initiatives in animal health, equipment and machinery -- through extensive field demonstrations, information dissemination, and initiatives to develop the capacity of private sector input dealers and service providers to meet farm demand. It is also making credit more accessible to cash-strapped farm households and agribusinesses, investing in productive infrastructure, and collaborating with MAAH in developing policies - laws, norms, regulations, etc. - conducive to expanding crop and livestock production.

Crop and livestock yields will increase through the introduction of new, practical technologies, such as improved seed quality and plant varieties, better cultivation, irrigation, and harvesting methods, improved livestock breeds, improved feeds and feeding practices, and improved livestock health practices. RAMP will conduct on-farm production demonstrations in its priority regions to maximize the dissemination and adoption of improved technologies. RAMP will expose at least 500,000 farm households to the technologies in question, promoting their adoption over the life of the program. In the end, RAMP will have a direct impact on at least 3.5 million people, or one seventh of Afghanistan's population.

On the infrastructure front, RAMP will enhance farmer competitiveness through the rehabilitation of rural irrigation systems. A typical small-scale irrigation system, consisting of diversion dams, canals and kerezes, supports 500 to 1000 hectares of cultivated land. RAMP will rehabilitate approximately 615 such systems, returning up to 300,000 to 600,000 hectares of cultivated land to full irrigated production. In general, bringing crop land under irrigation has the effect of doubling yields.

\section{Increasing Incomes Through Effective Linkages Among Producers, Processors, and Markets}

RAMP will reduce off-farm marketing costs by introducing agribusiness traders, processors, distributors, and exporters to practices that reduce post-harvest losses, improve market timing, and reduce transportation, storage, handling, and distribution costs. RAMP will assist agribusinesses sourcing from its 500,000 target farm households in improving their business, post-harvest handling, processing, storage, and brokerage practices. It will give particular attention to enterprises that expand women's economic participation. The improved practices will result in reductions in marketing costs, which in turn will have the practical effect of reducing market prices and expanding market volumes.

RAMP will further strengthen agricultural markets by expanding financial services to micro, small, and medium-sized agribusinesses. RAMP will provide capital to qualified Afghan finance nongovernmental organizations (NGOs) and other financial institutions to on-lend to agribusinesses along value chains in each of the program's priority sub-sectors -- poultry, dried fruit and nuts, cotton, fresh

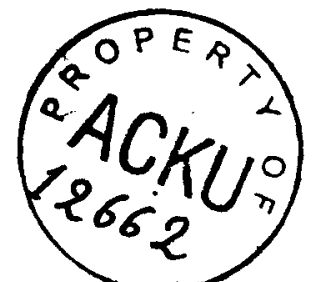


vegetables, and food grains. The program will give special consideration for lending to enterprises owned and operated by women.

RAMP will also strengthen the competitiveness of priority value chains through the rehabilitation of roads and local market facilities. These activities will complement the capital-intensive investments USAID is financing under a separate program. Most secondary and tertiary roads connecting rural villages to district and regional markets are so poorly maintained as to make passage of vehicular traffic impossible, or to allow traffic to pass at very low speeds and high risk of damage. These conditions translate either into high transport costs, where roads are passable, or into virtual isolation of rural village markets, where they are not. The upshot is high prices for consumers and limited production and marketing possibilities for farmers. RAMP will repair approximately 1,000 kilometers of rural roads. Under the assumption that a typical village connector road is five kilometers, about 2,000 villages in RAMP priority regions will be able to bring in seeds, fertilizer, and other inputs, and to sell crop and livestock products off farm. Farm-to-market transportation costs will fall by at least ten percent.

\section{Estimated Financial Obligations}

Estimating conservatively, RAMP will issue job orders in the amount of $\$ 55$ million under its first three program components during calendar year 2004. The breakdown of the dollar value of the job orders among the three components is:
Agricultural Technology and Market Development
$\$ 15$ million
Rural Financial Services
$\$ 10$ million
Rural Infrastructure Rehabilitation
$\$ 30$ million

Over the life of the program, RAMP foresees issuing job orders in the amount of $\$ 132.5$ million. The distribution of this total among the first three program components is: Agricultural Technology and Market Development, \$40 million; Rural Financial Services, \$25 million; and Rural Infrastructure Rehabilitation, $\$ 67.5$ million. This last amount includes $\$ 20$ million obligated separately under the REFS contract.

\section{Component 1. Agricultural technology \& market development}

The agricultural technology and market development component is divided into three technical areas: a) input supply for crop production, b) livestock development, and c) post harvest, processing, and marketing.

\section{Input supply for crop production:}

Objective: To rebuild Afghanistan's agronomic and horticultural crop production system by introducing new and improved seeds, fertilizers, crop protection chemicals and by teaching farmers and agri-input dealers in their proper and best uses.

\section{Input supply for crop products job orders:}

1.1. Clean Seed Production, Multiplication, and Marketing. This job order will support the operations of the potato tissue culture laboratory and further equip and regularly train personnel in basic seed production and screen house management. It wills also provide formal training on tissue culture in a regional facility to a selected candidate who will manage the facility; train farmer seed multipliers in the selected provinces; supply trained farmers with seed; provide technical supervision, field demonstrations etc. to help increase production. Establish and operate a variety selection system; construct and adapt seed stores for participating farmers in higher elevations and cold storage for seed producers in the plains where required. Develop a seed marketing and promotion plan among seed producing groups and train professionals, officers of the Ministry of Agriculture and other 
participating organizations in priority subjects related to potato seed production, seed certification and marketing.

\section{$>$ Subcontractor: (Future Harvest Consortium/CIP), $\$ 662,000$}

1.2. Village-Based Enterprise Development in Afghanistan. This project will develop village-based seed enterprises in selected farming communities. Each enterprise will comprise a group of progressive farmers. The enterprises will be made fully operational and profitable, each producing quality seed per year on land contributed by the farmers themselves. The farmer seed enterprises will undertake all agronomic and post-harvest operations with technical assistance from Consortium members and staff of the Ministry of Agriculture and Livestock. The seed will be mechanically processed, packaged, tested for quality status, stored and sold directly or through dealers (village traders and merchants) and NGOs to other farmers in the community and beyond.

New germplasm resources for oilseeds and cotton will be introduced into the system in the spring of

2004. Training programs in business management and seed technology will be held each year for entrepreneurs and seed distributors participating in the project. In addition, there will be farmers' field days to show what quality seed of improved varieties can do for farmers.

\section{$>$ Subcontractor: Future Harvest Consortium/ICARDA, $\$ \mathbf{1 , 9 2 8 , 0 0 0}$}

\subsection{Demonstrating New Technologies in Farmers' Fields to Facilitate Rapid Adoption and Diffusion.}

The project will establish on-farm demonstrations in a total of 27 districts within the five provinces of Kunduz, Nangarhar, Parwan, Ghazni, and Helmand. Demonstrations will focus on six principal crops of wheat, rice, mung bean, potato, onion and tomato, and key inputs and management practices, including improved varieties, fertilizer, seed rate, weed control, irrigation scheduling, and transplanting of rice and onions. The project will organize field days and invite farmers from neighboring communities to visit the demonstrations, and explain the technical aspects of the demonstrations and the benefits derived from adoption. The project will also provide information for public awareness campaigns (leaflets, radio broadcasts, etc) to be conducted by RAMP. As the project progresses, the project will assess the extent of adoption of improved practices by farming communities, by following up with all farmers who have visited the demonstrations and/or attended farmers' field days.

\section{$>$ Subcontractor: Future Harvest Consortium/ICARDA, $\mathbf{\$ 1 , 8 9 9 , 0 0 0}$}

\section{Introducing Protected Agriculture for Cash Crop Production in Marginal and Water Deficit Areas of Afghanistan}

The project will promote the adoption of affordable and sustainable protected agricultural systems to produce high value crops, using marginal or otherwise non-productive lands and water more efficiently, by establishing a central demonstration and training site within Kabul and by installing simple greenhouse structures at selected pilot sites with participating farmers. The project will establish a Protected Agriculture Center at the Ministry of Agriculture's Badam Bagh Research \& Livestock Station, in Kabul for demonstration, technical backstopping and training. Introduction of plastic house facilities and production practices to farmers in 28 selected pilot sites. Training programs in plastic house installation, preparation and management (including plug trays), and in integrated production and protection management (IPPM), On-the-job training for farmers, national agricultural research staff, extension agents and technicians within Afghanistan and in leading farms outside Afghanistan. Targeted research at the pilot sites with full participation of farmers to address farmers' needs and solve location-specific problems, including testing and selection of most suitable greenhouse crops, growing techniques, IPPM and pre- and post-harvest handling and management.

\section{$>$ Subcontractor: Future Harvest Consortium/CIP), $\mathbf{\$ 1 , 6 2 5 , 0 0 0}$}

\subsection{Agri-Input Dealer Training and Development. (multi-part)}

Agri Input Dealer Training. Training programs will be provided covering several aspects of the agricultural input business at a basic and subsequently at an advanced level, initially in the five priority provinces and later in all others. The number of programs and subjects presented will vary by 
province depending on the total number of dealers doing business in that province, whether they are retail dealers, retail and wholesale dealers, or wholesale/importer dealers, their levels of education, and years of business experience, and their knowledge of and experience in selling seeds and crop protection products.

Agri Input Developing Dealer Linkages with Suppliers and financial institutions. A series of regional trade missions and meetings will be held during year one to provide direct contacts with the Mazar urea plant, between dealers and distributors in Kabul, Jalalabad, Kandahar and other towns, with regional input suppliers in Uzbekistan and Pakistan, and with international agricultural input suppliers.

The project will initially seek the support of registered hawalas to channel trade credit to identified distributors and larger retailers, as described in rural credit program. Training in credit management will be concentrated on the wholesaler/distributors at first. This training will be held in conjunction with MISFA financial institutions that are supported by or funded by RAMP.

Agri Input Dealer Association Building. The input dealers in the five priority provinces and later all provinces will be encouraged to establish provincial or regional trade associations using IFDC experience gained from successful structured development of such in Albania and Kosovo.

Inputs Management Information System. Work will continue to collect, analyze and disseminate market prices for all farm inputs.

$>$ Subcontractor: IFDC, $\$ \mathbf{2 , 5 2 1 , 0 0 0}$

\section{Agri-Input Regulatory Reform (IFDC).}

Two major activities will be undertaken: a) Establishment of an Inspection and Sampling Unit within the Project; and b) Market-Based Agricultural Input Regulatory Systems (fertilizer, CPP, and Seed).

\section{$>$ Subcontractor: IFDC, $\mathbf{\$ 4 , 1 4 2 , 0 0 0}$}

\section{Livestock development:}

The objectives of the livestock component are to develop or re-develop the livestock sector in Afghanistan and to improve its efficiency. This will be accomplished through improved livestock health, production and marketing practices.

\section{Livestock development activities/job orders:}

\subsection{Poultry production project (FAO).}

Family-style village-level production is still the predominant poultry system in Afghanistan. It is based on indigenous chickens scavenging for feed supply. Women almost exclusively deal with village poultry production. The contribution of rural poultry production to the Afghan economy is significant and exceeds more than $98 \%$ of national output of poultry products. However, the indigenous breeds have very low production potential with annual mortality of chickens often reaching more than $50 \%$ of the population under the traditional system. The most important constraints to the system are considered to be: (i) inadequate technical knowledge of the producers; (ii) unavailability of vaccines for the prevention of important diseases; and (iii) lack of other input supplies and health services.

The proposed project deals directly with these issues. It will deal with the knowledge issue through direct training, starting with the training of trainers and passing down to village level. The training will be effected through village-level Poultry Producer Groups, which past experience has shown have a strong catalytic impact in encouraging women to further extend their knowledge. The PPGs will form the focus for the supply of improved breeding stock, the delivery of appropriate vaccines and medicines and the supply of other necessary inputs for raising productivity.

$>$ Grantee: Food and Agriculture Organization (FAO), $\$ 3,625,000$ 


\subsection{Livestock Health, Production, and Marketing Improvement Project}

The proposed project will: a) Create a national network of private veterinary field units (VFU) capable of providing livestock health services in all 380 districts of Afghanistan; b) Train sufficient numbers of para-veterinarians (paravets) required to staff and service the national network; c) Create a sustainable vaccine, medicines, and equipment supply and distribution system throughout

Afghanistan; d) Create a livestock health, production, and marketing information system that links this private network with government departments on such issues as disease surveillance, livestock inventories, and trans-border issues; e) Utilize the national network of VFUs for outreach and promotion of livestock health, production, and marketing issues; and e) Collaborate with the existing public/private livestock policy working group on policy reform issues.

\section{Subcontractor: Dutch Committee for Afghanistan (DCA), $\$ 12,300,000$}

\section{Post harvest, processing, and marketing objectives:}

Introduce improved post harvest technologies (transportation, handling, and storage) in order to lower losses and increase quality.

$>$ Rebuilding and introducing appropriate processing technologies that increase the value of agricultural commodities.

$>$ Improved access to domestic, regional, and international markets by lowering marketing costs through efficient infrastructure development and technology transfer.

\section{Post harvest, processing, and marketing activities:}

Conceptually, the post harvest, processing, and marketing activities will focus on a demand-driven approach. The demand for post harvest (e.g., storage, cleaning, and grading of grains, legumes, and other crops), processing (e.g., sorting, dehusking, milling, and pressing), and marketing (e.g., distributing, packaging, branding) activities is linked to a value chain.

As business people with risk capital are identified with plans to invest in the downstream processing and marketing of agricultural products, processors, traders, and post harvest enterprises involved in the upstream activities will also be engaged in improving product quality by upgrading their equipment and machinery, production volumes, etc.

\section{Component 2. Rural Financial Services}

The objective of the rural finance component is to create self-sustainable financial intermediaries to facilitate the long term growth of the Afghan agricultural sector. Agricultural incomes should increase with access to rural finance based on a demand-driven approach and private sector principles working through a broad spectrum of financial intermediation including microfinance institutions, credit unions, non-bank financial institutions and commercial banks.

In order to be sustainable, a financial institution will have to generate enough revenue through their lending products. The financial institution will need to cover costs through earned revenue. ${ }^{.}$. While at the same time, the financial institution needs to be efficient and control their expenses. Generally a financial institution expends more during their start-up phase; therefore, this indicator will initially be low and increase over time as the operations expand. It is essential that a financial institution will need to continuously increase their self-sufficiency ratio to maintain their equity.

\footnotetext{
'Any revenue from donors or other operations should not be included in this calculation because the financial institution needs to determine the viability of their operations through earned revenue.
} 


\section{Activities/job orders:}

The initial job order was approved for the Microfinance Investment and Support Facility-Afghanistan (MISFA). MISFA is a multi-donor, national wholesale funds facility supporting microfinance providers ${ }^{2}$ which have a diversified set of methodologies by product, geographic location, and gender with a mix of rural and urban programs. RAMP funding will be largely used $(\$ 4 \mathrm{M})$ to provide direct loan capital to microfinance providers that are providing financial services to meet the needs of the agriculture sector.

Ten microfinance providers have been pre-selected based on their applications to receive support through MISFA. The providers include both international PVOs and local NGOs. In addition to the loan capital, RAMP funding $(\$ 1 \mathrm{M})$ would be used for specific agro-related programs and products that need some technical assistance and/or capacity building. These funds would be available to fund capacity building associated with the particular activities being supported by RAMP.

Subsequent job orders will be issued to financial intermediaries who can provide financial services to small and medium agro-enterprises as well as larger investment projects. The institutions will be identified through a request for proposal (RFP) process. The RFP will be based on an assessment to determine which institutions or mechanisms are most appropriate for delivering financial services to the agricultural sector. The RFP will be drafted by an assessment team consisting of specialists in the fields of agricultural credit, credit unions, commercial banking and financial services in a post-conflict environment.

\section{Inputs/costs:}

The rural finance component consists of a total of $\$ 25 \mathrm{M}$ which ceiling amounts of $\$ 15 \mathrm{M}$ for job orders and $\$ 10 \mathrm{M}$ for grants.

\section{Activities:}

\section{MISFA $\$ 5,000,000$}

$>4 \mathrm{M}$ to be utilized for loan capital needs of pre-selected microfinance providers.

$>\$ 1 \mathrm{M}$ to be utilized for technical assistance needs regarding agricultural lending for the preselected microfinance providers. The technical assistance will include one-on-one support to the providers and, also, training targeted to the providers.

\section{Small, Medium, Large Loans $\$ 16,000,000$}

$>\$ 15 \mathrm{M}$ to be utilized for loan capital for small, medium and large size agro-enterprise loans.

$>\$ 1 \mathrm{M}$ to be utilized for technical assistance needs regarding agricultural lending for the financial intermediaries. RAMP will monitor the loan portfolios of the financial intermediaries for outreach and quality of loans to RAMP targeted borrowers.

\section{Department of Cooperatives $\$ \mathbf{\$ 5 0 , 0 0 0}$}

Grant funds to the Department of Cooperatives for capacity building.

$>$ Provide technical assistance directly on credit issues and coordinate with external consultants for further technical assistance needs.

\section{Targets/Results:}

Access to financing for the working capital and fixed assets needs for agro-enterprises,

$>$ Appropriate loan products for the agricultural sector, and

\footnotetext{
${ }^{2}$ The term "microfinance providers" is used in its broadest sense to refer to a variety of institutions, including but not limited to, NGOs, credit unions, savings and loans cooperatives, leasing companies, microfinance banks.
} 
$>$ Strong financial institutions which are integral parts of the financial landscape of Afghanistan.

Specifically, cumulative loans disbursed through the microfinance providers to the agricultural sector will total $\$ 4,000,000$ and reach 10,000 clients. The providers will maintain a high quality loan portfolio with $\mathrm{PAR}_{30}$ of at least $95 \%$. The providers will attain an operational self-sufficiency equal to at least $25 \%$.

Cumulative loans disbursed through the financial intermediaries for small, medium and large sized loans will total $\$ 3,000,000$ and reach 75 clients. The intermediaries will maintain a high quality loan portfolio with $\mathrm{PAR}_{30}$ of at least $95 \%$.

A grant of $\$ 50,000$ will be provided to the Ministry of Cooperatives for capacity building. The result will be a cooperative law updated and drafted.

\section{Component 3. Rural Infrastructure Rehabilitation}

The overall objective of rehabilitating rural infrastructure is to enable farmers to increase production and income as a result of reliable infrastructure.

$>$ Rehabilitation of Irrigation Systems: The objective of this subcomponent is to enable farmers to cultivate abandoned agricultural lands and supply a reliable source of water to areas currently underutilized because of water shortages

$>$ Rural Road Rehabilitation: The objective of this subcomponent is to provide farmers with improved access to markets and encourage farmers to increase production resulting from increased trader activity and lower transportation costs.

$>$ Post harvest, processing, and market structures: The objective of this subcomponent is to improve the environment for the commercialization of agriculture products and decrease spoilage resulting from improved processing and market facilities.

\section{Activities/job orders:}

\subsection{Renovation of the Char Dara and Bala Doori irrigation canal system.}

This project will de-silt more than 90 kilometers of primary irrigation canal systems and repair approximately 60 water control turn outs and gates. As a result of this work more than 36,000 hectares of prime agriculture land will receive a reliable source of water for irrigation. Work is in process and will be completed in time for the spring cultivation in late April.

\section{> Subcontractor: Development Alternatives Inc. (DAI), \$1,136,791}

\subsection{Construction of Check Dams.}

This project will construct 19 check dams to form community reservoirs to store rain water and prevent erosion. The strategically placed check dams will enable farmers to harvest rainwater and divert stored water to underground aquifers, recharging karezes.

\section{$>$ Subcontractor: Central Asia Development Group (CADG), \$706,917}

\subsection{Construction of a retaining wall and the rehabilitation of roads.}

The sub-contract to construct a 400 meter retaining wall to protect the Khanabad primary irrigation canal. Serious scouring from the Kanabad River is threatening the major canal system and only three meters remains from cutting into the main canal wall. Work has started and should be completed prior to the spring rains in April. Additionally, KRA will rehabilitate 25 kilometers of tertiary roads which includes the installation of 96 culverts and six reinforced concrete water washes. The road connects five villages with a total population of 21,621 families. The farmers residing along this road receive water from the Khanabad irrigation system, thereby linking the irrigation system to the road. 


\section{$>$ Subcontractor: Kunduz Rehabilitation Agency (KRA), $\$ \mathbf{4 5 0 , 0 0 0}$}

\subsection{Road training activities.}

RAMP has formed a partnership with the UNOPS to provide road training for NGOs selected or may be chosen to participate in the tertiary road improvement component. A series of road renovation training courses will be provided. The training consists of two weeks classrooms road standards and design training based on engineering norms and standards which will be used under RAMP. This academic training will be followed by one month of on-site hands-on practical training. The initial classroom academic training will start November $9^{\text {th }}$ and continue through November $21^{\text {st }}$

\subsection{Other infrastructure activities.}

Approximately eight or nine additional infrastructure Job Orders will be approved prior to the spring of 2004. Once these Job Orders are approved the RAMP engineering staff will devote much of its time to assure that construction schedules are met and that the construction work conforms to approved designs. An arrangement has been agreed to with the Ministry of Irrigation to assign its regional engineers to supervise the construction efforts of the NGOs. Since these engineers are permanent employees of the Ministry of Irrigation they will only receive per-diem under RAMP. Utilizing the Ministry engineers for construction supervision frees up the RAMP engineers to respond to ad-hoc requests from USAID. An example of such requests is when USAID determined that RAMP should conduct the Helmand irrigation technical and environmental assessments. This assessment is a major initiative and will require approximately ten weeks to complete.

\section{Inputs/costs:}

The rural infrastructure component is budgeted at $\$ 67$ million of which $\$ 20$ million has been allocated for the REFS project. The follow provides an illustrative concept for programming the remaining $\$ 47$ million. Understandably, these projections may shift depending on priorities and need within each infrastructure category.

Rehabilitation of Irrigation Systems, \$25.5 million. While both rural roads and irrigation systems are in dire need of repair, we propose to allocate a larger share of resources for irrigation systems, since the impact for irrigation systems is immediate and the World Bank has an ongoing road improvement project managed by the UNOPS and implemented by the Ministry of Public Works. The systems which will be renovated include water diversion dams, water intakes, desilting and cleaning of primary irrigation canals and replacement irrigation gates.

Rural Road Rehabilitation, $\$ 15$ million. Subject to the availability of funds, approximately 1000 kilometers ( 350 kilometers in 2004) of rural roads will be renovated which conform to recognized engineering norms and standards. Road construction will combine community labor with light equipment such as walk behind compactors and water trucks. An added input will be the community labor employed during the construction phase.

Post harvest, processing, and market structures, $\$ 7$ million. Potential post harvest, processing, and market structures shall be assessed and selected by RAMP in conjunction with counterpart institutions, NGOs and the communities. Structures could consist of market stalls, grain storage facilities, fruit processing, cold storage facilities and storage and loading facilities at the Kabul airport.

Road training activities. Training costs estimated at $\$ 16,000$ per course. 


\section{Agricultural policy}

\section{Policy Dialogue to Support Agricultural Competitiveness}

RAMP will assist the MAAH in strengthening its leadership of the natural resources component of the National Development Program. Much of the MAAH's success in strengthening agricultural competitiveness will depend on the extent to which it is able to formulate and implement policies that ensure sustainable use of Afghanistan's fragile land, water and forest resource base. This will require close and continuous coordination with the Ministries of Rural Rehabilitation and Development, Irrigation, Water Resources and Environment, Public Works, Commerce and Light Industries, and Finance, and stakeholders to identify the constraints to RAMP objectives.

Policy dialogue with the TISA government will be continuous in order to reduce/eliminate obstacles to private sector investment for modernizing agriculture. RAMP will support this effort by providing a senior policy advisor to directly advise the Minister of Agriculture, and a ministerial liaison advisor to assist in the coordination of RAMP activities across all relevant TISA ministries. The prioritization of these policies will be coordinated with the various Ministries.

As part of the overall policy dialogue with the Ministry of Agriculture and Animal Husbandry, Chemonics will work with senior key ministry staff to develop a new vision of the MAAH, taking it from an implementing ministry (where it provided the services directly to farmers) toward becoming a private sector facilitator and regulatory ministry. While developing a shared vision is the first step, ministry-wide acceptance and implementation of this new direction for the MAAH may take some time. Integrating select Chemonics professional staff with their natural MAAH counterparts is the first step. But even that will be a challenge as this ministry is still being rebuilt (physically as well as institutionally) almost from the ground up since it ceased to function for years during the war and most of its buildings and facilities were destroyed by the fighting.

\section{Facilitate Coordination at the Ministerial Level}

The Government of Afghanistan has established a Consultative Group (CG) framework, within which the National Budget is planned, financed and implemented. Consultative Groups will be convened by the chair Ministry, supported by a donor or donor/UN agency Focal Point. Other concerned ministries will participate, as will the major donors, UN agencies, and representative NGOs.

Developing these linkages and integrating them with the mainstream government functions is critical to the success of the project and the longer term development of the MAAH. Rather than creating parallel structures, RAMP will build on existing process such as the CGs and the TWGs. This will not only avoid duplication, but substantially reduce the efforts as these processes are now fairly well understood by both Government and donors. Longer term, this will create essential links across these ministries and assist the development of effective government.

\section{Activities:}

\subsection{MAAH Strategy paper.}

Objective: Main objective of this paper would be to improve agricultural productivity per unit of land and water, and to reduce marketing and transaction costs for agricultural inputs and outputs.

Impact: Increase efficiency of water use, enhance coordination between institutions involved in agriculture, and improve food security and rural employment. 


\subsection{Policy formation advisory services.}

Objective: To train and upgrade the skill of the Department of Planning in project formulation, monitoring and evaluation activities.

Result: Better performance of the Department in their activities, and improved coordination and liaison with RAMP staff; Promote participation of private sector in agriculture; Enhance cooperation between different institutions serving agriculture.

\subsection{Seed policy and Marketing Study:}

Objective: To formulate proper policy guideline for the Government to take in order to mitigate the problem in delivering improved seed; and To assist the private sector to get a greater part in seed production and distribution.

Result: With timely availability of improved seed, the farmers would be able to increase crop yield and their income.

\subsection{Policy and Marketing Study of Chemical Fertilizer.}

Objectives: Review the fertilizer importation and distribution operation and come up with specific mitigation policy and marketing strategy measures in order to improve private trade.

Result: Provide a study for RAMP and Ministry of Agriculture to follow in order to assist private traders in delivery of fertilizer and enhance accessibility of chemical fertilizer with proper quality to the farmers. 


\section{ANNEX A. RAMP COMPONENT LOG FRAME}

Table 1.

\section{Component 1. Agricultural technology and market development}

Objectives:

1.1. In put supply for crop production: To rebuild Afghanistan's agronomic and horticultural crop production system by introducing new and improved seeds, fertilizers, crop protection chemicals and by teaching farmers and agri-input dealers in their proper and best uses.

1.2. Livestock development: The objectives of the livestock component are to develop or re-develop the livestock sector in Afghanistan and to improve its efficiency. This will be accomplished through improved livestock health, production and marketing practices.

1.3 Post harvest, processing, and marketing: Introduce improved post harvest technologies (transportation, handling, and storage) in order to lower losses and increase quality. Rebuilding and introducing appropriate processing technologies that increase the value of agricultural commodities. Improved access to domestic, regional, and international markets by lowering marketing costs through efficient infrastructure development and technology transfer.

\begin{tabular}{|c|c|c|c|}
\hline Activities & Inputs/costs & Indicators & Targets/Results \\
\hline $\begin{array}{l}\text { Clean Seed } \\
\text { Production, } \\
\text { Multiplication, } \\
\text { and Marketing } \\
\text { (Future Harvest } \\
\text { Consortium/CIP) }\end{array}$ & $\begin{array}{l}\text { Potato seed - CIP } \\
\text { - US\$ } 0.662 \\
\text { million }\end{array}$ & $\begin{array}{l}\text { + Number of farmers } \\
\text { trained to be seed producers } \\
\text { with increased income. } \\
+ \text { Number of commercial } \\
\text { potato farmers using } \\
\text { improved varieties } \\
\text { Improvement in existing } \\
\text { yields. } \\
+ \text { An operational in vitro } \\
\text { based seed production } \\
\text { laboratory and screen } \\
\text { houses established and } \\
\text { functioning in Kabul } \\
+ \text { Ministry of Agriculture } \\
\text { Extension Agents will be } \\
\text { trained in virus-free potato } \\
\text { production and yield trialing } \\
+ \text { Number of on-farm stores } \\
\text { for potato seed storage will } \\
\text { be built } \\
+ \text { Seed produced from the } \\
\text { program sold through } \\
\text { "organized marketing } \\
\text { chains" to local potato } \\
\text { producers. }\end{array}$ & $\begin{array}{l}\text { + Over } 350 \text { small farmers per year } \\
\text { are expected to become trained seed } \\
\text { producers with an anticipated total } \\
\text { income of about US } \$ 2-5 \text { million. } \\
+ \text { The yield benefits of quality seed } \\
\text { are expected to be dispersed to about } \\
3,500 \text { commercial potato farmers per } \\
\text { year who in turn will have yield } \\
\text { increases of about } 30 \% \text { over existing } \\
\text { yields. } \\
+ \text { An operational in vitro based seed } \\
\text { production laboratory and screen } \\
\text { houses established and functioning in } \\
\text { Kabul. } \\
+15 \text { Ministry of Agriculture } \\
\text { Extension Agents per year will be } \\
\text { trained in virus-free potato } \\
\text { production and yield trialing } \\
+20 \text { farmers per year will be trained } \\
\text { in virus-free potato production in } \\
\text { selected districts. } \\
+ \text { On-farm stores for potato seed } \\
\text { storage will be built in each } \\
\text { province. } \\
+ \text { Seed produced from the program } \\
\text { sold through "organized marketing } \\
\text { chains" to local potato producers. }\end{array}$ \\
\hline & Inputs/costs & & \\
\hline $\begin{array}{l}\text { Village-Based } \\
\text { Enterprise } \\
\text { Development in } \\
\text { Afghanistan } \\
\text { (Future Harvest } \\
\text { Consortium/ICAR } \\
\text { DA) }\end{array}$ & $\begin{array}{l}\text { Village Seed } \\
\text { Enterprises - } \\
\text { ICARDA - US\$ } \\
1.928 \text { million }\end{array}$ & $\begin{array}{l}\text { + Number of village-based } \\
\text { seed enterprises in target } \\
\text { provinces. } \\
\text { + Number of business plans } \\
\text { will have been developed } \\
\text { and implementation by seed } \\
\text { enterprises. } \\
\text { + Volume of improved seed } \\
\text { produced for distribution of } \\
\text { a multitude of crops. }\end{array}$ & $\begin{array}{l}\text { + This project will develop } 5 \text { village- } \\
\text { based seed enterprises in year one. } \\
\text { + Simple business plan will have been } \\
\text { developed and implementation started } \\
\text { for at least } 5 \text { farmer group seed } \\
\text { enterprises (i.e., } 50 \text { entrepreneurial } \\
\text { farmers), by the end of the first year. } \\
+ \text { The village based seed enterprises } \\
\text { will produce annually approximately } \\
667 \text { MT of seed of a multitude of }\end{array}$ \\
\hline
\end{tabular}




\begin{tabular}{|c|c|c|c|}
\hline & & $\begin{array}{l}\text { + Number of profitable seed } \\
\text { multiplication businesses. } \\
\text { + Increased yields for target } \\
\text { crops. } \\
\text { + Number of } \\
\text { farmers/extension agents } \\
\text { trained }\end{array}$ & $\begin{array}{l}\text { crops. } \\
+ \text { Quality seed will benefit at least } \\
40,000 \text { farm families annually, } \\
\text { resulting in } 10 \% \text { yield increase for } \\
\text { target crops. } \\
+ \text { By the end of the first year } 60 \\
\text { farmers/extension agents will have } \\
\text { been trained in training courses. } \\
+ \text { Field days and farmers meetings } \\
\text { have exposed } 250 \text { farmers to the } \\
\text { technologies used in the production } \\
\text { and marketing of seed. }\end{array}$ \\
\hline Activities & Inputs/costs & Indicators & Targets/Results \\
\hline $\begin{array}{l}\text { Demonstrating } \\
\text { New Technologies } \\
\text { in Farmers' Fields } \\
\text { to Facilitate Rapid } \\
\text { Adoption and } \\
\text { Diffusion (Future } \\
\text { Harvest } \\
\text { Consortium/ICAR } \\
\text { DA) }\end{array}$ & $\begin{array}{l}\text { Demo Plots - } \\
\text { ICARDA - US\$ } \\
1,899 \text { million }\end{array}$ & $\begin{array}{l}\text { + Increased yields from use } \\
\text { of improved package of } \\
\text { practices. } \\
+ \text { Number of Best Practice } \\
\text { Guides, in the form of } \\
\text { brochures and booklets, in } \\
\text { both Dari and Pashtun } \\
\text { developed and distributed. } \\
+ \text { Number of farmers from } \\
\text { surrounding communities } \\
\text { that visit the } \\
\text { demonstrations. } \\
+ \text { Proportion of farmers in } \\
\text { surrounding communities } \\
\text { making use of demonstrated } \\
\text { technologies } \\
+ \text { Increased net returns from } \\
\text { use of new technologies. }\end{array}$ & $\begin{array}{l}\text { + Significantly increased yields from } \\
\text { use of improved package of practices } \\
\text { (Target }=25-35 \% \text { increase in yield). } \\
+ \text { Best Practice Guides, in the form } \\
\text { of brochures and booklets, in both } \\
\text { Dari and Pashtun. } \\
+500 \text { farmers from surrounding } \\
\text { communities visit the } \\
\text { demonstrations. } \\
+ \text { Proportion of farmers in } \\
\text { surrounding communities making } \\
\text { use of demonstrated technologies } \\
\text { (Target }=75 \% \text { ). } \\
+ \text { Increased net returns from use of } \\
\text { new technologies (Target }=20 \% \text { ). }\end{array}$ \\
\hline Activities & Inputs/costs & Indicators & Targets/Results \\
\hline $\begin{array}{l}\text { Introducing } \\
\text { Protected } \\
\text { Agriculture for } \\
\text { Cash Crop } \\
\text { Production in } \\
\text { Marginal and } \\
\text { Water Deficit } \\
\text { Areas of } \\
\text { Afghanistan } \\
\text { (Future Harvest } \\
\text { Consortium/ICAR } \\
\text { DA) }\end{array}$ & $\begin{array}{l}\text { Protected Agric. - } \\
\text { ICARDA - US } \$ \\
1,625 \text { million }\end{array}$ & $\begin{array}{l}\text { + Established local private } \\
\text { sector plastic green house } \\
\text { fabrication workshop. } \\
\text { + Protected Agriculture } \\
\text { Center (PAC) in Kabul for } \\
\text { demonstration, training and } \\
\text { technical backstopping, } \\
\text { equipped with all necessary } \\
\text { equipment and facilities. } \\
\text { + Number of productive } \\
\text { greenhouse enterprises } \\
\text { established. } \\
\text { + Market database for } \\
\text { greenhouse crops } \\
\text { established. } \\
\text { + Number of farmers and } \\
\text { extension agents trained in } \\
\text { greenhouse installation and } \\
\text { management. } \\
+ \text { Number of technicians } \\
\text { (extension agents) trained in } \\
\text { a commercial greenhouse } \\
\text { enterprise outside } \\
\text { Afghanistan. } \\
\text { + Number of training } \\
\text { manuals and technical }\end{array}$ & $\begin{array}{l}\text { + Established local private sector } \\
\text { plastic house fabrication workshop. } \\
\text { + Protected Agriculture Center } \\
\text { (PAC) in Kabul for demonstration, } \\
\text { training and technical backstopping, } \\
\text { equipped with all necessary } \\
\text { equipment and facilities. } \\
+9 \text { productive greenhouse } \\
\text { enterprises established with } \\
\text { participating farmers. } \\
+ \text { Market database for greenhouse } \\
\text { crops established. } \\
+86 \text { farmers and extension agents } \\
\text { trained in greenhouse installation and } \\
\text { management. } \\
+4 \text { technicians (extension agents) } \\
\text { trained in a commercial greenhouse } \\
\text { enterprise outside Afghanistan. } \\
+ \text { Total of four training manuals and }\end{array}$ \\
\hline
\end{tabular}




\begin{tabular}{|c|c|c|c|}
\hline & & $\begin{array}{l}\text { booklets in the local } \\
\text { language. } \\
+ \text { Recommendations on best } \\
\text { practices, production plans } \\
\text { and financial analyses to } \\
\text { support expansion of } \\
\text { protected agriculture and } \\
\text { farmers' investment in } \\
\text { greenhouse production. }\end{array}$ & $\begin{array}{l}\text { technical booklets in the local } \\
\text { language. } \\
\text { + Recommendations on best } \\
\text { practices, production plans and } \\
\text { financial analyses to support } \\
\text { expansion of protected agriculture } \\
\text { and farmers' investment in } \\
\text { greenhouse production. }\end{array}$ \\
\hline Activities & Inputs/costs & Indicators & Targets/Results \\
\hline $\begin{array}{l}\text { Agri-Input Dealer } \\
\text { Training and } \\
\text { Development } \\
\text { (IFDC). }\end{array}$ & $\begin{array}{l}\text { Agri-Input Dealer } \\
\text { Training - IFDC - } \\
\$ 4.142 \text { million }\end{array}$ & $\begin{array}{l}\text { + Number of dealers } \\
\text { trained. } \\
+ \text { Number of sustainable } \\
\text { provincial or regional trade } \\
\text { associations. } \\
+ \text { Volume of fertilizer } \\
\text { utilized. } \\
+ \text { Volume of increased sales } \\
\text { of improved variety seed } \\
\text { and crop protection } \\
\text { products. }\end{array}$ & $\begin{array}{l}\text { + More than } 335 \text { dealers will be } \\
\text { trained in the first year and at these } \\
\text { training session plans for } \\
\text { establishment of dealer associations } \\
\text { will be presented and discussed. } \\
+ \text { Sustainable provincial or regional } \\
\text { trade associations will be developed } \\
\text { by the end of year } 2 \text { and a national } \\
\text { association by year } 3 \text {. } \\
+ \text { Fertilizer consumption will be } \\
\text { doubled from about } 170,000 \mathrm{MT} \text { in } \\
2002 \text { to about } 400,000 \text { tons in } 2006 \\
\text { with an increase in the range of } \\
\text { products offered to address major } \\
\text { and micronutrient deficiencies. } \\
+ \text { Substantial increases in the sales of } \\
\text { improved variety seed and crop } \\
\text { protection products. } \\
+ \text { Improved seed supplies will be } \\
\text { marketed through private sector } \\
\text { dealers for all crops. } \\
+ \text { Trained dealers will market CPP } \\
\text { products. }\end{array}$ \\
\hline Activities & Inputs/costs & Indicators & Targets/Results \\
\hline $\begin{array}{l}\text { Agri-Input } \\
\text { Regulatory } \\
\text { Reform (IFDC). }\end{array}$ & $\begin{array}{l}\text { Agri-Input } \\
\text { Regulatory } \\
\text { Reform - IFDC - } \\
\$ 2.521 \text { million }\end{array}$ & $\begin{array}{l}\text { + Inspection and sampling } \\
\text { unit for fertilizer, seed, and } \\
\text { CPP transferred to the } \\
\text { public sector. } \\
+ \text { Fertilizer, seed, and CPP } \\
\text { reports detailing the } \\
\text { requirements } \\
\text { (documentation, technical } \\
\text { assistance, training, } \\
\text { equipment, etc.) for } \\
\text { establishing regulatory } \\
\text { systems in Afghanistan } \\
\text { prepared. } \\
+ \text { Number of draft laws and } \\
\text { regulations for fertilizer, } \\
\text { seed, and CPP reviewed and } \\
\text { prepared. } \\
+ \text { Documents required for } \\
\text { implementing and operating } \\
\text { these regulatory systems } \\
\text { prepared. }\end{array}$ & $\begin{array}{l}\text { + Transfer of a trained inspection } \\
\text { and sampling unit for fertilizer, seed, } \\
\text { and CPP to the public sector no later } \\
\text { than project end. } \\
\text { + Preparation of fertilizer, seed, and } \\
\text { CPP reports detailing the } \\
\text { requirements (documentation, } \\
\text { technical assistance, training, } \\
\text { equipment, etc.) for establishing } \\
\text { regulatory systems in Afghanistan. } \\
\text { + Preparation and/or review of draft } \\
\text { laws and regulations for fertilizer, } \\
\text { seed, and CPP. } \\
\text { + Preparation of all documents } \\
\text { required to implement and operate } \\
\text { these regulatory systems. }\end{array}$ \\
\hline Activities & Inputs/costs & Indicators & Targets/Results \\
\hline $\begin{array}{l}\text { Poultry } \\
\text { production project } \\
\text { (FAO). }\end{array}$ & $\begin{array}{l}\text { Poultry program } \\
-\mathrm{FAO}-\$ 3.6 \\
\text { million }\end{array}$ & $\begin{array}{l}+ \text { Number of village women } \\
\text { managing layers and } \\
\text { producing eggs } \\
+ \text { Number of poultry }\end{array}$ & $\begin{array}{l}+ \text { Training of } 115 \text { technical staff who } \\
\text { will operate from the five provincial } \\
\text { centers; } \\
+ \text { Training of } 8,000 \text { village women }\end{array}$ \\
\hline
\end{tabular}




\begin{tabular}{|c|c|c|c|}
\hline & & $\begin{array}{l}\text { producer groups organized } \\
\text { and functioning } \\
+ \text { Number of feed mills } \\
\text { operational } \\
+ \text { Number of eggs produced } \\
+ \text { Number of eggs marketed } \\
\text { through poultry producers }\end{array}$ & $\begin{array}{l}\text { in all aspects of poultry management, } \\
\text { feeding and marketing; } \\
\text { + Implementation of a vaccination } \\
\text { programme against Newcastle } \\
\text { Disease in all target villages; } \\
\text { + Training of a group leader for each } \\
\text { Poultry Producer Group who would } \\
\text { be provided with the necessary } \\
\text { inputs for the provision of regular } \\
\text { services to village poultry farmers; } \\
\text { + Development of the organizational } \\
\text { structure of the Poultry Producer } \\
\text { Groups at the provincial level. } \\
\text { + Establishment of a revolving fund } \\
\text { to allow for the future operation of } \\
\text { Poultry Producer Groups; } \\
\text { + Establishment of small feed } \\
\text { processing units which would } \\
\text { prepare mixed feed for village } \\
\text { poultry farmers in each of the five } \\
\text { target provinces; } \\
\text { + Establishment of a supply and } \\
\text { storage system for vaccines and } \\
\text { poultry medicines in the provincial } \\
\text { centers. }\end{array}$ \\
\hline Activities & Inputs/costs & Indicators & Targets/Results \\
\hline $\begin{array}{l}\text { Livestock Health, } \\
\text { Production, and } \\
\text { Marketing } \\
\text { Improvement } \\
\text { Project (DCA). }\end{array}$ & $\begin{array}{l}\text { Livestock health, } \\
\text { production, and } \\
\text { marketing - DCA } \\
-12.3 \text { million } \\
\end{array}$ & $\begin{array}{l}\text { + Number of vaccination } \\
\text { campaigns implemented; } \\
\text { preventive treatment } \\
\text { activities implemented; and } \\
\text { new veterinary field units } \\
\text { established. } \\
\text { + Number of paravet trained } \\
\text { and livestock health } \\
\text { seminars conducted. } \\
\text { + Number of vaccine and } \\
\text { medication supply system } \\
\text { established. } \\
\text { + Livestock health, } \\
\text { production, and marketing } \\
\text { information collected; } \\
\text { information distribution } \\
\text { network established; } \\
\text { + Number of livestock } \\
\text { health, production, and } \\
\text { marketing bulletins } \\
\text { developed. } \\
\text { + Number of livestock } \\
\text { policy committee meetings } \\
\text { held and livestock health, } \\
\text { production, and marketing } \\
\text { memoranda produced; and } \\
\text { workshops or symposia } \\
\text { organized. }\end{array}$ & $\begin{array}{l}\text { + Decrease in annual mortality of } \\
\text { young stock (lambs, calves and } \\
\text { kids), in areas covered, by up to } 25 \% \\
\text { over a three-year period (as } \\
\text { compared to: in the absence of any } \\
\text { intervention). } \\
\text { + Decrease in annual mortality of } \\
\text { adult stock in areas covered by up to } \\
40 \% \text {, depending on the species } \\
\text { + Annual increase in livestock } \\
\text { numbers, in areas covered, of the } \\
\text { order of } 10 \% \\
+ \text { Increase in production from } \\
\text { livestock, in areas covered, of } 5 \% \\
\text { due to reduction in disease } \\
\text { + Increasing the coverage of the } \\
\text { network of VFUs, allowing basic } \\
\text { animal health care for all livestock to } \\
\text { reach a greater number of families. } \\
\text { + Increasing the number of animals } \\
\text { treated (estimated at } 1,000 \text { per } \\
\text { paravet / year), given anthelmintic } \\
\text { (estimated at } 5,000 \text { per paravet per } \\
\text { year) and vaccinated (estimated at } \\
20,000 \text { per paravet per year) in areas } \\
\text { where new paravets are introduced. } \\
+ \text { Increasing the number of } \\
\text { veterinary personnel, by upgrading } \\
\end{array}$ \\
\hline
\end{tabular}




\begin{tabular}{|l|l|l|}
\hline $\mid$ & $\begin{array}{l}\text { their knowledge and skills and by } \\
\text { gaining official acceptance of } \\
\text { paravets, the quality of preventive } \\
\text { and curative veterinary health care } \\
\text { will improve. } \\
\text { + Calving, lambing, and kidding } \\
\text { rates for herds protected by paravets } \\
\text { would be higher than those where } \\
\text { there was no access to veterinary } \\
\text { services. } \\
\text { + Neonatal mortality and mortality } \\
\text { around weaning time would be } \\
\text { reduced in cattle } \\
\text { + Post weaning mortality in all } \\
\text { species should be reduced } \\
\text { significantly } \\
\text { + Productive output of adult } \\
\text { livestock should be increased, } \\
\text { growth rate of immature livestock } \\
\text { should also increase } \\
+ \text { Knowledge of the disease situation } \\
\text { is required to predict disease } \\
\text { movement and establish control } \\
\text { mechanisms. } \\
\text { + Marketing information will be a } \\
\text { valuable source of data, just like } \\
\text { disease surveillance data. }\end{array}$ \\
\hline
\end{tabular}


Table 2.

\section{Component 2. Rural financial services}

Objectives:

The objective of the rural finance component is to create self-sustainable financial intermediaries to facilitate the long term growth of the Afghan agricultural sector. Agricultural incomes should increase with access to rural finance based on a demand-driven approach and private sector principles working through a broad spectrum of financial intermediation including microfinance institutions, credit unions, non-bank financial institutions and commercial banks.

\begin{tabular}{|c|c|c|c|}
\hline Activities & Inputs/costs & Indicators & Targets/Results \\
\hline $\begin{array}{l}\text { Microfinance } \\
\text { Investment and } \\
\text { Support Facility- } \\
\text { Afghanistan } \\
\text { (MISFA) }\end{array}$ & $\begin{array}{l}\text { Loan Capital - \$4M for } 10 \\
\text { pre-selected microfinance } \\
\text { providers } \\
\text { Technical Assistance - } \\
\text { \$1M for agricultural related } \\
\text { lending programs and to } \\
\text { develop agriculture lending } \\
\text { products } \\
\text { Steering Committee - } \\
\text { provide input on the } \\
\text { proposals submitted to } \\
\text { MISFA from the } 10 \text { pre- } \\
\text { selected microfinance } \\
\text { providers }\end{array}$ & $\begin{array}{l}\text { Loan Portfolio: } \\
\text { Outreach: } \\
\text { Loans Disbursed } \\
\text { Number of Clients } \\
\text { Served } \\
\text { Portfolio Quality: } \\
\text { Portfolio at Risk } 30 \text { days } \\
\text { Institutional Capacity: } \\
\text { Financial Viability: } \\
\text { Operational Self- } \\
\text { Sufficiency }\end{array}$ & 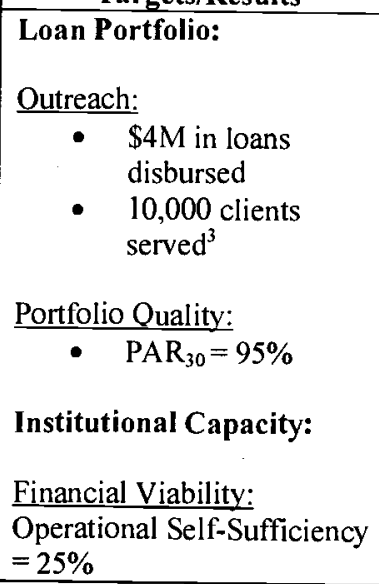 \\
\hline $\begin{array}{l}\text { Small and Medium } \\
\text { Loans and Larger } \\
\text { Investments }\end{array}$ & $\begin{array}{l}\text { Loan Capital - \$15M } \\
\text { Technical Assistance - } \\
\$ 1 \mathrm{M} \text { for agricultural related } \\
\text { lending programs and to } \\
\text { develop agriculture lending } \\
\text { products }\end{array}$ & $\begin{array}{l}\text { Loan Portfolio: } \\
\text { Outreach: } \\
\text { Loans Disbursed } \\
\text { Number of Clients } \\
\text { Served } \\
\text { Portfolio Quality: } \\
\text { Portfolio at Risk } 30 \text { days }\end{array}$ & $\begin{array}{l}\text { Loan Portfolio: } \\
\begin{array}{c}\text { Outreach: } \\
\qquad \begin{array}{l}\text { \$3M in loans } \\
\text { disbursed }\end{array} \\
-\quad 75 \text { clients served } \\
\end{array} \\
\text { Portfolio Quality: } \\
- \text { PAR }_{30}=95 \%\end{array}$ \\
\hline Cooperatives & $\begin{array}{l}\text { Technical Assistance - } \\
\$ 50,000 \text { grant for providing } \\
\text { technical assistance to the } \\
\text { Cooperatives Department } \\
\text { under the Ministry of } \\
\text { Agriculture and Animal } \\
\text { Husbandry } \\
\end{array}$ & $\begin{array}{l}\text { Active cooperatives in } \\
\text { RAMP targeted } \\
\text { provinces are assessed } \\
\text { for their needs. }\end{array}$ & $\begin{array}{l}\text { Cooperative law updated } \\
\text { and drafted. }\end{array}$ \\
\hline
\end{tabular}

\footnotetext{
${ }^{3}$ Based on an average loan size of $\$ 400$

${ }^{4}$ Based on an average loan size of $\$ 40,000$
} 
Table 3.

\section{Component 3. Rural Infrastructure Rehabilitation}

Objectives: The overall objective of rehabilitating rural infrastructure is to enable farmers to increase production and income as a result of reliable infrastructure.

3.1 Rehabilitation of Irrigation Systems: Enable farmers to cultivate abandoned agricultural lands and supply a reliable source of water to areas currently underutilized because of water shortages

3.2 Rural Road Rehabilitation: Provide farmers with improved access to markets and encourage farmers to increase production resulting from increased trader activity and lower transportation costs.

3.3 Post harvest, processing, and market structures: Improve the environment for the commercialization of agriculture products and decrease spoilage resulting from improved processing and market facilities.

\begin{tabular}{|c|c|c|c|}
\hline Activities & Inputs/costs & Indicators & Targets/Results \\
\hline $\begin{array}{l}\text { Renovation of the } \\
\text { Char Dara and } \\
\text { Bala Doori } \\
\text { irrigation canal } \\
\text { system. }\end{array}$ & $\begin{array}{l}\text { Development } \\
\text { Alternatives Inc. } \\
\text { (DAI) was awarded } \\
\text { a sub-contract in the } \\
\text { amount of } \\
\$ 1,136,791\end{array}$ & $\begin{array}{l}\text { + Kilometers of primary } \\
\text { irrigation canal systems } \\
\text { de-silted } \\
+ \text { Number of water } \\
\text { control turn outs and } \\
\text { gates repaired. } \\
+ \text { Number of workers } \\
\text { employed } \\
+ \text { Amount of dollars } \\
\text { provided to community } \\
\text { through labor }\end{array}$ & $\begin{array}{l}\text { + De-silt more than } 90 \text { kilometers of } \\
\text { primary irrigation canal systems } \\
\text { + Repair approximately } 60 \text { water } \\
\text { control turn outs and gates } \\
\text { As a result of this work more than } \\
36,000 \text { hectares of prime agriculture } \\
\text { land will receive a reliable source of } \\
\text { water for irrigation. }\end{array}$ \\
\hline Activities & Inputs/costs & Indicators & Tar \\
\hline $\begin{array}{l}\text { Construction of } 19 \\
\text { Check Dams. }\end{array}$ & \begin{tabular}{|l|} 
The Central Asia \\
Development Group \\
(CADG) received a \\
sub-contract for \\
$\$ 706,917$
\end{tabular} & $\begin{array}{l}\text { + Number of check dams } \\
\text { constructed to form } \\
\text { community reservoirs to } \\
\text { store rain water and } \\
\text { prevent erosion. } \\
\text { + Number of Kerezes } \\
\text { which receive recharge } \\
\text { of water } \\
\text { + Number of workers } \\
\text { employed }\end{array}$ & $\begin{array}{l}\text { + Construct } 19 \text { check dams to form } \\
\text { community reservoirs to store rain } \\
\text { water and prevent erosion. } \\
\text { The strategically placed check dams } \\
\text { will enable farmers to harvest } \\
\text { rainwater and divert stored water to } \\
\text { underground aquifers, recharging } \\
\text { karezes. }\end{array}$ \\
\hline Activities & Inputs/costs & Indicators & Targets \\
\hline $\begin{array}{l}\text { Construction of } \\
\text { retaining wall and } \\
\text { the rehabilitation } \\
\text { of roads. }\end{array}$ & \begin{tabular}{|l|} 
The Kunduz \\
Rehabilitation \\
Agency (KRA) was \\
awarded a $\$ 450,000$ \\
sub-contract
\end{tabular} & $\begin{array}{l}\text { + Number of meters of } \\
\text { retaining wall to protect } \\
\text { the Khanabad primary } \\
\text { irrigation canal. } \\
\text { + Kilometers of tertiary } \\
\text { roads which includes the } \\
\text { installation of culverts } \\
\text { and reinforced concrete } \\
\text { water washes. } \\
\text { + Number of workers } \\
\text { employed } \\
\text { + Dollars provided to } \\
\text { communities through } \\
\text { hired labor } \\
\end{array}$ & $\begin{array}{l}\text { + Construct a } 400 \text { meter retaining } \\
\text { wall to protect the primary irrigation } \\
\text { canal. } \\
\text { + Rehabilitate } 25 \text { kilometers of } \\
\text { tertiary roads and installation of } 96 \\
\text { culverts and } 6 \text { reinforced concrete } \\
\text { water washes. } \\
\text { + Number of families with improved } \\
\text { access to markets } \\
\text { + Number of hectares planted with } \\
\text { high-value crops because of } \\
\text { improved access to markets } \\
\text { The road connects five villages with } \\
\text { a total population of } 21,621 \text { families. }\end{array}$ \\
\hline Activities & Inputs/costs & Indicators & Targets/Results \\
\hline $\begin{array}{l}\text { Road training } \\
\text { activities. } \\
\text { RAMP has formed } \\
\text { a partnership with } \\
\text { the UNOPS to } \\
\text { provide road } \\
\text { training for NGOs }\end{array}$ & $\begin{array}{l}\text { Training costs } \\
\$ 16,000 \text { per course }\end{array}$ & $\begin{array}{l}\text { + Number of road } \\
\text { renovation training } \\
\text { courses provided. } \\
\text { The training consists of } \\
\text { two weeks classrooms } \\
\text { road standards and } \\
\text { design training based on }\end{array}$ & $\begin{array}{l}\text { + A series of three road renovation } \\
\text { training courses will be provided. } \\
\text { + Capacity developed by } 15 \mathrm{NGOs} \\
\text { to construct quality roads } \\
+ \text { This academic training will be } \\
\text { followed by one month of on-site } \\
\text { hands-on practical training. }\end{array}$ \\
\hline
\end{tabular}




\begin{tabular}{|c|c|c|c|}
\hline $\begin{array}{l}\text { selected or may be } \\
\text { chosen to } \\
\text { participate in the } \\
\text { tertiary road } \\
\text { improvement } \\
\text { component. }\end{array}$ & & $\begin{array}{l}\text { engineering norms and } \\
\text { standards which will be } \\
\text { used under RAMP. } \\
\text { This academic training } \\
\text { will be followed by one } \\
\text { month of on-site hands- } \\
\text { on practical training. }\end{array}$ & $\begin{array}{l}\text { + Approximately two kilometers of } \\
\text { this } 26 \text { kilometer road may be } \\
\text { rehabilitated during the on-site } \\
\text { practical training. } \\
+350 \text { kilometers of roads } \\
\text { constructed which meet engineering } \\
\text { standards } \\
+ \text { NGOs which received training } \\
\text { acquire road rehabilitation funds } \\
\text { from RAMP and other donors, } \\
\text { resulting from improved capacity }\end{array}$ \\
\hline Activities & Inputs/costs & Indicators & Targets/Results \\
\hline $\begin{array}{l}\text { Rehabilitation of } \\
\text { Irrigation Systems } \\
\text { The systems which } \\
\text { will be renovated } \\
\text { include water } \\
\text { diversion dams, } \\
\text { water intakes, de- } \\
\text { silting and cleaning } \\
\text { of primary } \\
\text { irrigation canals and } \\
\text { replacement } \\
\text { irrigation gates. }\end{array}$ & $\begin{array}{l}\text { \$25 million } \\
\text { Approximately } 10 \\
\text { separate sub- } \\
\text { contracts in size } \\
\text { from } \$ 500 \text { thousand } \\
\text { to } \$ 12 \text { million. } \\
\text { Once these Job } \\
\text { Orders are approved } \\
\text { the RAMP } \\
\text { engineering staff } \\
\text { will devote much of } \\
\text { its time to assure that } \\
\text { construction } \\
\text { schedules are met } \\
\text { and that the } \\
\text { construction work } \\
\text { conforms to } \\
\text { approved designs. }\end{array}$ & $\begin{array}{l}\text { + Number of structures } \\
\text { built } \\
+ \text { Number of irrigation } \\
\text { canals functioning } \\
+ \text { Number of } \\
\text { communities receiving a } \\
\text { reliable source of water } \\
+ \text { Number of workers } \\
\text { employed } \\
+ \text { Dollars provided to } \\
\text { communities through } \\
\text { hired labor } \\
+ \text { Number of kilometers } \\
\text { of irrigation canals de- } \\
\text { silted } \\
+ \text { Increased yields from } \\
\text { improved irrigation } \\
\text { systems will pass the } \\
\text { projected } 25 \% \text { increase } \\
\text { mentioned in the RAMP } \\
\text { contract. }\end{array}$ & $\begin{array}{l}\text { + Water associations functioning to } \\
\text { ration water and maintain irrigation } \\
\text { system } \\
+ \text { Vital irrigation structures repaired } \\
\text { as identified in assessments } \\
+ \text { Increased income resulting from } \\
\text { increased and improved production } \\
\text { practices } \\
+ \text { Technical capacity developed with } \\
\text { NGOs to continue rehabilitating } \\
\text { irrigation systems } \\
+ \text { Number of refugees returned as a } \\
\text { result of access to irrigated land for } \\
\text { cultivation }\end{array}$ \\
\hline Activities & Inputs/costs & Indicators & Targets/Results \\
\hline $\begin{array}{l}\text { Rural Road } \\
\text { Rehabilitation } \\
\text { Subject to the } \\
\text { availability of } \\
\text { funds, } \\
\text { approximately } 1000 \\
\text { kilometers ( } 350 \\
\text { kilometers in } 2004) \\
\text { of rural roads will } \\
\text { be renovated which } \\
\text { conform to } \\
\text { recognized } \\
\text { engineering norms } \\
\text { and standards. }\end{array}$ & $\begin{array}{l}\text { \$15million } \\
\text { Approximately } 7 \\
\text { sub-contracts } \\
\text { ranging in size from } \\
\$ 500 \text { thousand to } \$ 4 \\
\text { million. }\end{array}$ & $\begin{array}{l}\text { + Number of kilometers } \\
\text { of roads improved } \\
\text { + Number of culverts } \\
\text { constructed } \\
\text { + Numbers and meters of } \\
\text { bridges constructed } \\
+ \text { Number of workers } \\
\text { employed } \\
+ \text { Amount of money } \\
\text { spent in communities } \\
\text { through labor }\end{array}$ & $\begin{array}{l}\text { + Number of families or } \\
\text { communities with improved access } \\
\text { to markets } \\
\text { + Increased production, through } \\
\text { access to improved inputs } \\
\text { + Increased plantings of high-valued } \\
\text { crops because of easy access to } \\
\text { markets } \\
\text { + Increased number of buyers } \\
\text { resulting in higher prices to farmers. } \\
\text { + Improved social services i.e., } \\
\text { teachers, medical } \\
\text { + Improved transportation services, } \\
\text { availability and lower costs }\end{array}$ \\
\hline Activities & Inputs & Indicators & Targets/Results \\
\hline $\begin{array}{l}\text { Potential market } \\
\text { structures shall be } \\
\text { assessed and } \\
\text { selected by RAMP } \\
\text { in conjunction with } \\
\text { counterpart } \\
\text { institutions, NGOs }\end{array}$ & \$7million & $\begin{array}{l}\text { + Number of market } \\
\text { centers constructed. } \\
+ \text { Number of high- } \\
\text { valued crop processing } \\
\text { facilities } \\
+ \text { Number of grain } \\
\text { storage facilities } \\
\text { constructed. } \\
+ \text { Number of families } \\
\text { with on-farm storage }\end{array}$ & $\begin{array}{l}\text { + Decreased spoilage due to } \\
\text { improved market facilities } \\
+ \text { Increased number of farmers that } \\
\text { can store and market production } \\
\text { surplus } \\
+ \text { Decrease in post-harvest losses by } \\
10 \% \\
+ \text { Increased ability to export fresh }\end{array}$ \\
\hline
\end{tabular}




\begin{tabular}{|l|l|l|l|}
\hline $\begin{array}{l}\text { and the } \\
\text { communities. }\end{array}$ & $\begin{array}{l}\text { facilities. } \\
+\% \text { reduction in post } \\
\text { harvest losses. } \\
\text { + Number of cold } \\
\text { storage facilities } \\
\text { constructed. } \\
\text { + Number of improved } \\
\text { storage and loading } \\
\text { facilities developed. }\end{array}$ & \\
& & \\
\hline
\end{tabular}

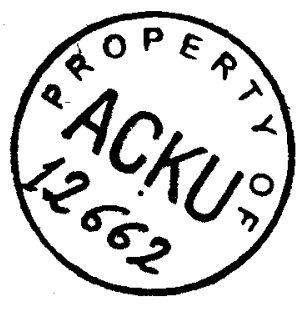

